\title{
Use of aromatase inhibitor in a girl with peripheral precocious puberty
}

\author{
CY Lee*, SW Cheng, LK Lee \\ From 7th APPES Biennial Scientific Meeting \\ Nusa Dua, Bali. 14-17 November 2012
}

This girl presented with problem of vaginal bleeding at 6 year 2 month old. There was no medication history. Physical examination showed that she was tall with height $122.7 \mathrm{~cm} \mathrm{(97^{ \text {th } }}$ percentile) and weight was 23.1 $\mathrm{Kg}\left(75-90^{\text {th }}\right.$ percentile). Early pubertal sign was present with Breast stage 2 and pubic hair stage 1 . She did not have skin pigmentation and has no bone deformity or fracture. Investigations suggested peripheral precocious puberty with grossly elevated serum estradiol 2293 $\mathrm{pmol} / \mathrm{L}$ with suppressed $\mathrm{LH}<0.2 \mathrm{IU} / \mathrm{L}$ and $\mathrm{FSH}<0.2$ $\mathrm{IU} / \mathrm{L}$, which also failed to rise in the Gonadotrophin stimulation test. Bone age was advanced to 7 to 8 year old. Pelvic ultrasound showed a $3.6 \mathrm{~cm}$ cystic lesion in left ovary and the uterus size was prominent with endometrial echoes. Skeletal survey did not show bony lesion. The clinical diagnosis was peripheral precocious puberty from autonomous functioning ovary cyst.

The girl showed progression with recurrent vaginal bleeding and further breast development. To stop further vaginal bleeding and prevent later compromised height, Letrozole, an aromatase inhibitor, was commenced at dose of $1.25 \mathrm{mg}$ daily. Breast size regressed and serum estradiol dropped to nadir of $<73 \mathrm{pmol} / \mathrm{L}$. The ovary cyst resolved 2 months after starting Letrozole but was again detected after stopped treatment at 7 years old. The girl went into true puberty around when she approached 9 year old with progression of breast development and growth spurt. The height at last follow up at 10- year 10 month old was $154 \mathrm{~cm}\left(97^{\text {th }}\right.$ percentile) and has not yet started menarche. Repeated ultrasound at 8 year 9 month old showed that the ovary cyst again resolved.

The case demonstrated that the potent, long-acting aromatase inhibitor Letrozole is effective in arresting sexual precocious puberty resulting from autonomous functioning ovary cyst. The girl goes into normal

Department of Paediatrics \& Adolescent Medicine, Caritas Medical Centre, Hong Kong

C) Biomed Central puberty and attains growth spurt. Further follow up is required to monitor normal menstruation pattern.

Published: 3 October 2013

doi:10.1186/1687-9856-2013-S1-P74

Cite this article as: Lee et al:: Use of aromatase inhibitor in a girl with peripheral precocious puberty. International Journal of Pediatric

Endocrinology 2013 2013(Suppl 1):P74.
Submit your next manuscript to BioMed Central and take full advantage of:

- Convenient online submission

- Thorough peer review

- No space constraints or color figure charges

- Immediate publication on acceptance

- Inclusion in PubMed, CAS, Scopus and Google Scholar

- Research which is freely available for redistribution
() Biomed Central 